\title{
Anti-inflammatory Activities of New Succinic and Maleic Derivatives from the Fruiting Body of Antrodia camphorata
}

\author{
Shim-Chang Chien, ${ }^{\dagger}$ Miaw-Ling Chen, ${ }^{\ddagger}{ }^{\ddagger}$ Hsiou-Ting Kuo, ${ }^{\S}$ \\ YAO-ChInG Tsai, ${ }^{\S}$ BI-Fong Lin, ${ }^{\nabla, \#}$ AND Yueh-Hsiung KuO ${ }^{*}, \dagger, \S, \perp, I I, \#$
}

\begin{abstract}
Department of Chemistry, National Taiwan University, Taipei, Taiwan; Department of Health Sciences, Chang Jung Christian University, Tainan, Taiwan; Department of Biochemical Science and Technology, Institute of Microbiology and Biochemistry, College of Life Science, National

Taiwan University, Taipei, Taiwan; Center for Food and Biomolecules, National Taiwan

University, Taipei, Taiwan; Agricultural Biotechnology Research Center, Academia Sinica,

Taipei, Taiwan; and Tsuzuki Institute for Traditional Medicine, College of Pharmacy, China Medical University, Taichung, Taiwan.
\end{abstract}

\begin{abstract}
Six new compounds, trans-3-isobutyl-4-[4-(3-methyl-2-butenyloxy)phenyl]pyrrolidine-2,5-dione (1), trans1-hydroxy-3-(4-hydroxyphenyl)-4-isobutylpyrrolidine-2,5-dione (2), cis-3-(4-hydroxyphenyl)-4-isobutyldihydrofuran-2,5-dione (3), 3-(4-hydroxyphenyl)-4-isobutyl-1 H-pyrrole-2,5-dione (4), 3-(4-hydroxyphenyl)-4isobutylfuran-2,5-dione (5), and dimethyl 2-(4-hydroxyphenyl)-3-isobutylmaleate (6), together with one known compound, 3-isobutyl-4-[4-(3-methyl-2-butenyloxy)phenyl]furan-2,5-dione (7), were isolated from the fruiting bodies of Antrodia camphorata. The structures of the compounds were elucidated by analysis of their spectroscopic data. To investigate the immunomodulatory potential of the compounds, RAW264.7 macrophage cells were treated with the compounds. Compound 1 significantly increased spontaneous TNF- $\alpha$ secretion from unstimulated RAW264.7 cells but suppressed IL-6 production [50\% inhibition concentration value $\left(\mathrm{IC}_{50}\right)=10 \mu \mathrm{g} / \mathrm{mL}$ ] in LPS-stimulated cells. Compounds $\mathbf{3}, \mathbf{4}$, and $\mathbf{6}$ also suppressed IL-6 production with $\mathrm{IC}_{50}$ values of 17,18 , and $25 \mu \mathrm{g} / \mathrm{mL}$, respectively, suggesting that these four compounds may have an anti-inflammatory effect on macrophage-mediated responses. Of the six compounds, compound $\mathbf{1}$ was the most effective, exerting both immunostimulatory and anti-inflammatory effects.
\end{abstract}

KEYWORDS: Antrodia camphorata; succinic acid derivative; maleic acid derivative; macrophage; TNF$\alpha$; IL-6

\section{INTRODUCTION}

Antrodia camphorataWu, Ryvarden \& Chang (Polyporaceae, Aphyllophorales) is native to Taiwan. Its fruiting body is a very rare and expensive mushroom that grows slowly in the wild and is difficult to cultivate in the greenhouse. The fruiting body of $A$. camphorata (= Taiwanofungus camphorata) has traditionally been used as an herbal medicine in Taiwan and is commonly known by the names "jang-jy" and "niu-chang-chih" (1). In the wild, it grows on the inner

* Author to whom correspondence should be addressed (telephone 886-2-33661671; fax 886-2-23636359; e-mail yhkuo@ntu.edu.tw).

$\dagger$ Tsuzuki Institute for Traditional Medicine, China Medical University.

\# Department of Health Sciences, Chang Jung Christian University.

${ }^{\nabla}$ Department of Biochemical Science and Technology, National Taiwan University.

${ }^{\S}$ Department of Chemistry, National Taiwan University.

${ }^{\perp}$ Agricultural Biotechnology Research Center, Academia Sinica.

"Center for Food and Biomolecules, National Taiwan University.

" Equal contribution to this paper. heartwood wall of Cinnamomun kanehirai Hay (Lauraceae), an endemic and endangered species in Taiwan. In traditional herbal medicine, A. camphorata fruiting bodies have been utilized as treatment for food and drug intoxications, diarrhea, abnormal pains, hypertension, itchy skin, and liver cancer $(2,3)$. The biological activities of the fruiting body $(4,5)$ and cultured mycelia (6-8) of A. camphorata have been studied. The wild-type fruiting body contains fatty acids, lignans, phenylderivatives, sesquiterpenes, steroids, and triterpenoids (1,9-14). The mycelium was studied by Nakamura et al., who purified maleic and succinic acid derivatives. Both the wild-type and mycelium possessed antiproliferative activity against a Lewis lung carcinoma (LLC) tumor cell line (8). The methanol extracts of A. camphorata also showed potential antiinflammatory effects, and the effects seen with a solid-state culture were similar to those of the wild fruiting body (15). The first studies on the fruiting body of this fungus in a solid culture were achieved by Chen et al. (16), who evaluated five labdane-type diterpenes (including three new compounds) 
Table 1. ${ }^{1} \mathrm{H}$ NMR Data of Compounds $1-7\left(400 \mathrm{MHz}, 1-3\right.$ and 5-7 in $\mathrm{CDCl}_{3}, 4$ in $\left.\mathrm{CD}_{3} \mathrm{OD}\right)$

\begin{tabular}{|c|c|c|c|c|c|c|c|}
\hline no. & 1 & 2 & 3 & 4 & 5 & 6 & 7 \\
\hline 1 & 7.94 br s & & & & & & \\
\hline \multicolumn{8}{|l|}{2} \\
\hline 3 & $2.97 \mathrm{dt}(5.2,5.2)$ & $3.68 d(5.0)$ & $3.59 \mathrm{~d}(11.1)$ & & & & \\
\hline 4 & $3.60 \mathrm{~d}(5.2)$ & $2.91 \mathrm{~m}$ & $3.17 \mathrm{td}(11.1,3.6)$ & & & & \\
\hline \multicolumn{8}{|c|}{ 等, } \\
\hline $1^{\prime}$ & $1.54 \mathrm{~m}$ & $1.75-1.85 \mathrm{~m} 1.60 \mathrm{~m}$ & $1.37 \mathrm{~m} 1.70 \mathrm{~m}$ & $2.48 \mathrm{~d}(7.6)$ & $2.56 \mathrm{~d}(7.2)$ & $2.14 d(7.2)$ & $2.59 \mathrm{~d}(7.0)$ \\
\hline $2^{\prime}$ & $1.83 \mathrm{~m}$ & $1.75-1.85 \mathrm{~m}$ & $1.61 \mathrm{~m}$ & $1.99 \mathrm{~m}$ & $2.08 \mathrm{~m}$ & $1.70 \mathrm{~m}$ & $2.12 \mathrm{~m}$ \\
\hline $3^{\prime}$ & $0.71 \mathrm{~d}(6.4)$ & $0.69 \mathrm{~d}(6.3)$ & $0.91 \mathrm{~d}(6.5)$ & $0.87 d(6.8)$ & $0.91 \mathrm{~d}(6.7)$ & $0.77 d(6.8)$ & $0.94 \mathrm{~d}(6.8)$ \\
\hline $4^{\prime}$ & $0.89 \mathrm{~d}(6.4)$ & $0.88 \mathrm{~d}(6.3)$ & $0.97 d(6.5)$ & $0.87 \mathrm{~d}(6.8)$ & $0.91 \mathrm{~d}(6.7)$ & $0.77 \mathrm{~d}(6.8)$ & $0.94 \mathrm{~d}(6.8)$ \\
\hline \multicolumn{8}{|c|}{ 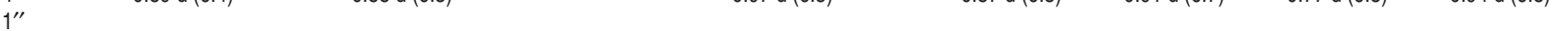 } \\
\hline $2^{\prime \prime}, 6^{\prime \prime}$ & $7.10 \mathrm{~d}(8.8)$ & $7.17 \mathrm{~d}(8.5)$ & $7.20 \mathrm{~d}(8.6)$ & $7.43 \mathrm{~d}(9.0)$ & $7.54 \mathrm{~d}(8.8)$ & $7.09 \mathrm{~d}(8.2)$ & $7.50 \mathrm{~d}(8.8)$ \\
\hline $3^{\prime \prime}, 5^{\prime \prime}$ & $6.88 \mathrm{~d}(8.8)$ & $6.83 \mathrm{~d}(8.5)$ & $6.75 \mathrm{~d}(8.6)$ & $6.87 \mathrm{~d}(9.0)$ & $6.94 \mathrm{~d}(8.8)$ & $6.81 \mathrm{~d}(8.2)$ & $7.02 \mathrm{~d}(8.8)$ \\
\hline \multicolumn{8}{|l|}{$4^{\prime \prime}$} \\
\hline $1^{\prime \prime \prime \prime}$ & $4.47 d(6.8)$ & & & & & & $4.57 d(6.6)$ \\
\hline $2^{\prime \prime \prime}$ & 5.46 br t $(6.8)$ & & & & & & $5.50 \mathrm{brt}(6.6)$ \\
\hline \multicolumn{8}{|l|}{$3^{\prime \prime \prime}$} \\
\hline $4^{\prime \prime \prime}$ & $1.72 \mathrm{~s}$ & & & & & & $1.76 \mathrm{~s}$ \\
\hline $5^{\prime \prime \prime}$ & $1.78 \mathrm{~s}$ & & & & & & $1.81 \mathrm{~s}$ \\
\hline $1-\mathrm{OCH}_{3}$ & & & & & & $3.70 \mathrm{~s}$ & \\
\hline $4-\mathrm{OC} \overline{\mathrm{H}}_{3}$ & & & & & & $3.80 \mathrm{~s}$ & \\
\hline
\end{tabular}

in vitro for their neuroprotective activity. Recently, Chen et al. (17) have also reported anti-inflammatory benzenoid constituents from the fruiting body of wild-type A. camphorata. Interestingly, they found it contains an acetylene functionality. Here, we isolated and characterized three new succinic acid derivatives, three new maleic acid derivatives, and one previously known compound from the fruiting body of A. camphorata in a solid culture and studied the antiinflammatory activity of their methanol extracts. To our knowledge, this is the first time maleic acid and succinic acid derivatives have been isolated from the fruiting body of A. camphorata in a solid culture.

\section{MATERIALS AND METHODS}

General Experimental Procedures. Melting points were determined with a Yanagimoto micromelting point apparatus and are uncorrected. IR spectra were recorded on a Perkin-Elmer $983 \mathrm{G}$ spectrophotometer. ${ }^{1} \mathrm{H},{ }^{13} \mathrm{C}$, and DEPT spectra were acquired on a Bruker DMX-400 spectrometer, and two-dimensional NMR spectra were acquired on a Bruker DMX-500 spectrometer. EIMS, UV, and specific rotations were determined using a JEOL JMS-HX 300 spectrometer, a Hitachi S-3200 spectrometer, and a JASCO DIP-180 digital polarimeter, respectively. Extracts were initially fractionated on silica gel (Merck 70-230 mesh, 230-400 mesh, ASTM) and then purified with a semipreparative normal-phase HPLC column $(250 \times 10 \mathrm{~mm}, 7 \mu \mathrm{m}$, LiChrosorb Si 60) on an LDC Analytical-III system.

Plant Material. The solid cultural fruiting bodies of A. camphorata were identified and provided by Well Shine Biotechnology Development, Taipei, Taiwan. A voucher specimen was deposited at Well Shine Biotechnology Development Co. Ltd.

Extraction and Isolation. The fruiting bodies of solid culture $A$. camphorata $(3.0 \mathrm{~kg}$ ) were extracted with $\mathrm{MeOH}(12 \mathrm{~L})$ by maceration at room temperature $(4$ days $\times 3)$. After removal of $\mathrm{MeOH}$ under vacuum, $\mathrm{H}_{2} \mathrm{O}$ was added to bring the total volume to $1 \mathrm{~L}$. This suspended phase was partitioned with EtOAc $(1 \mathrm{~L} \times 3)$. Evaporation of the combined EtOAc layers afforded black syrup (212 g). The EtOAc fraction $(200 \mathrm{~g})$ was chromatographed on a Si gel column $(10 \times 70$ $\mathrm{cm}$, Merk 70-230 mesh) using $n$-hexane, EtOAc, and $\mathrm{MeOH}$ of increasing polarity as eluent to obtain nine fractions: fraction 1 [8000 $\mathrm{mL}, n$-hexane/EtOAc (19:1)], fraction 2 [7000 mL, $n$-hexane/EtOAc (9:1)], fraction 3 [6000 mL, $n$-hexane/EtOAc (8:2)], fraction 4 [10000 $\mathrm{mL}, n$-hexane/EtOAc (7:3)], fraction 5 [8000 mL, $n$-hexane/EtOAc (1: 1)], fraction 6 [9000 mL, $n$-hexane/EtOAc (1:3)], fraction $7(8000 \mathrm{~mL}$, EtOAc), fraction 8 [7000 mL, EtOAc/MeOH (1:1)], and fraction 9 (6000 $\mathrm{mL}, \mathrm{MeOH})$. HPLC of fraction 6 on a normal-phase column with
Table 2. ${ }^{13} \mathrm{C}$ Spectral Data of $\mathbf{1}-\mathbf{6}\left(100 \mathrm{MHz}, \mathbf{1}-\mathbf{3}\right.$ and $\mathbf{5}-\mathbf{7}$ in $\mathrm{CDCl}_{3}, \mathbf{4}$ in $\mathrm{CD}_{3} \mathrm{OD}$ )

\begin{tabular}{lrrrrrrr}
\hline \multicolumn{1}{c}{ no. } & $\mathbf{1}$ & $\mathbf{2}$ & $\mathbf{3}$ & $\mathbf{4}$ & $\mathbf{5}$ & $\mathbf{6}$ & $\mathbf{7}$ \\
\hline 1 & & & & & & 168.3 & \\
2 & 179.2 & 172.0 & 173.3 & 172.6 & 166.4 & 137.5 & 166.4 \\
3 & 48.3 & 49.7 & 53.9 & 138.7 & 140.0 & 140.1 & 139.8 \\
4 & 53.8 & 44.2 & 47.5 & 138.3 & 140.2 & 169.4 & 140.2 \\
5 & 177.4 & 173.0 & 174.1 & 173.5 & 165.5 & & 165.4 \\
$1^{\prime}$ & 40.6 & 40.1 & 40.9 & 32.4 & 33.6 & 39.1 & 33.6 \\
$2^{\prime}$ & 25.6 & 25.0 & 26.3 & 28.1 & 27.9 & 27.4 & 27.9 \\
$3^{\prime}$ & 23.0 & 22.4 & 23.1 & 22.0 & 22.6 & 22.4 & 22.7 \\
$4^{\prime \prime}$ & 21.4 & 20.7 & 20.6 & 22.0 & 22.6 & 22.4 & 22.7 \\
$1^{\prime \prime}$ & 128.5 & 128.5 & 128.0 & 120.5 & 120.0 & 127.1 & 119.9 \\
$2^{\prime \prime}, 6^{\prime \prime}$ & 128.7 & 129.3 & 129.5 & 131.0 & 131.3 & 130.4 & 131.1 \\
$3^{\prime \prime}, 5^{\prime \prime}$ & 115.4 & 115.6 & 115.0 & 115.2 & 116.0 & 115.3 & 115.1 \\
$4^{\prime \prime}$ & 158.6 & 156.8 & 156.8 & 158.8 & 158.2 & 155.5 & 160.9 \\
$1^{\prime \prime \prime}$ & 64.8 & & & & & & 65.0 \\
$2^{\prime \prime \prime}$ & 119.4 & & & & & & 118.7 \\
$3^{\prime \prime \prime}$ & 138.5 & & & & & & 139.1 \\
$4^{\prime \prime \prime}$ & 18.2 & & & & & & 25.2 \\
$5^{\prime \prime \prime}$ & 25.8 & & & & & 52.4 & \\
$1-\mathrm{OCH}_{3}$ & & & & & & 52.2 & \\
$4-\underline{\mathrm{C}}_{3}$ & & & & & & & \\
\hline
\end{tabular}

n-hexane/EtOAc (4:1) as eluent, $4 \mathrm{~mL} / \mathrm{min}$, afforded $\mathbf{1}$ (12.5 mg), 2 (22.6 mg), 3 (6.8 mg), 4 (9.4 mg), 5 (15.0 mg), 6 (13.2 mg), and 7 (8.9 $\mathrm{mg})$, respectively.

trans-3-Isobutyl-4-[4-(3-methyl-2-butenyloxy)phenyl]pyrrolidine2,5-dione (1). Colorless gum; $[\alpha]_{\mathrm{D}}^{25}+24.0(c 0.20, \mathrm{MeOH})$; IR $v_{\max }^{\text {film }}$ $\mathrm{cm}^{-1} 3256,2928,2657,1714,1612,1513,1469$; for ${ }^{1} \mathrm{H} \mathrm{NMR}\left(\mathrm{CDCl}_{3}\right.$, $400 \mathrm{MHz})$, see Table 1; for ${ }^{13} \mathrm{C}$ NMR $\left(\mathrm{CDCl}_{3}, 100 \mathrm{MHz}\right)$, see Table 2; EIMS $70 \mathrm{eV}, \mathrm{m} / \mathrm{z}$ (rel intenstiy) $315[\mathrm{M}]^{+}$(1), 260 (9), 247 (75), 191 (100), 176 (15), 133 (61), 69 (67); HREIMS, $\mathrm{m} / \mathrm{z}$ found, 315.1825 ; calcd for $\mathrm{C}_{19} \mathrm{H}_{25} \mathrm{NO}_{3}, 315.1828$.

trans-1-Hydroxy-3-(4-hydroxyphenyl)-4-isobutylpyrrolidine-2,5dione (2). White solid; mp $189-193{ }^{\circ} \mathrm{C} ;[\alpha]_{\mathrm{D}}^{25}+9.6($ c $0.11, \mathrm{MeOH})$; UV $\lambda_{\max }^{\mathrm{MeOH}} \mathrm{nm}(\log \epsilon) 221.0$ (4.16), 275.0 (3.46), 283.0 (3.38); IR $v_{\max }^{\text {film }}$ $\mathrm{cm}^{-1} 3349,2929,1716,1608,1510,1460,1214,1116,840$; for ${ }^{1} \mathrm{H}$ NMR $\left(\mathrm{CDCl}_{3}, 400 \mathrm{MHz}\right)$, see Table 1; for ${ }^{13} \mathrm{C}$ NMR $\left(\mathrm{CDCl}_{3}, 100\right.$ $\mathrm{MHz}$ ), see Table 2; EIMS $70 \mathrm{eV}, \mathrm{m} / \mathrm{z}$ (rel intensity) $263[\mathrm{M}]^{+}$(28), 207 (71), 179 (63), 137 (46), 133 (100), 107 (35); HREIMS, m/z found, 263.1159; calcd for $\mathrm{C}_{14} \mathrm{H}_{17} \mathrm{NO}_{4}, 263.1153$.

cis-3-(4-Hydroxyphenyl)-4-isobutyldihydrofuran-2,5-dione (3). White solid; $\mathrm{mp} 184-187^{\circ} \mathrm{C} ;[\alpha]_{\mathrm{D}}^{25}+3.2(c 0.03, \mathrm{MeOH}) ; \mathrm{UV} \lambda_{\max }^{\mathrm{MeOH}}$ $\mathrm{nm}(\log \epsilon) 229.0$ (4.27), 276.0 (3.62), 286.0 (3.57); IR $v_{\max }^{\text {film }} \mathrm{cm}^{-1} 3339$, 2955, 2919, 1830, 1785, 1664, 1598, 1506, 1449, 1214, 840; for ${ }^{1} \mathrm{H}$ $\mathrm{NMR}\left(\mathrm{CDCl}_{3}, 400 \mathrm{MHz}\right)$, see Table 1; for ${ }^{13} \mathrm{C} \mathrm{NMR}\left(\mathrm{CDCl}_{3}, 100\right.$ 
MHz), see Table 2; EIMS $70 \mathrm{eV}, \mathrm{m} / z$ (rel intensity) $248[\mathrm{M}]^{+}$(14), 220 (10), 176 (33), 133 (100), 107 (35); HREIMS, m/z found, 248.1050; calcd for $\mathrm{C}_{14} \mathrm{H}_{16} \mathrm{O}_{4}, 248.1044$

3-(4-Hydroxyphenyl)-4-isobutyl-1H-pyrrole-2,5-dione (4). Yellow needles; mp 199-201 ${ }^{\circ} \mathrm{C}$; UV $\lambda_{\max }^{\mathrm{MeOH}} \mathrm{nm}(\log \epsilon) 231.0$ (4.4), 269.0 (4.4), 360.0 (3.8); IR $v_{\max }^{\text {film }} \mathrm{cm}^{-1} 3401,2956,1723,1611,1513,1434$, 1269; for ${ }^{1} \mathrm{H}$ NMR $\left(\mathrm{CD}_{3} \mathrm{OD}, 400 \mathrm{MHz}\right)$, see Table 1 ; for ${ }^{13} \mathrm{C}$ NMR $\left(\mathrm{CD}_{3} \mathrm{OD}, 100 \mathrm{MHz}\right)$, see Table 2; EIMS $70 \mathrm{eV}, \mathrm{m} / \mathrm{z}$ (rel intensity) 245 $[\mathrm{M}]^{+}$(98), 203 (100), 132 (52), 131 (50); HREIMS, $\mathrm{m} / \mathrm{z}$ found, 245.1041; calcd for $\mathrm{C}_{14} \mathrm{H}_{15} \mathrm{NO}_{3}, 245.1048$.

3-(4-Hydroxyphenyl)-4-isobutylfuran-2,5-dione (5). Yellow oil; UV $\lambda_{\max }^{\mathrm{MeOH}} \mathrm{nm}(\log \epsilon): 227.0$ (4.16), 358.0 (3.79); IR $\nu_{\max }^{\text {film }} \mathrm{cm}^{-1}: 3436$, $1838,1759,1606,1513,1334,1228,1169,923$; For ${ }^{1} \mathrm{H}$ NMR $\left(\mathrm{CDCl}_{3}\right.$, $400 \mathrm{MHz})$, see Table 1; For ${ }^{13} \mathrm{C} \mathrm{NMR}\left(\mathrm{CDCl}_{3}, 100 \mathrm{MHz}\right)$, see Table 2; EIMS $70 \mathrm{eV}, \mathrm{m} / z$ (rel intensity) 246 [M] $^{+}$(3), 218 (2), 204 (5), 176 (10), 103 (21), 73 (44), 59 (100); HREIMS, $\mathrm{m} / \mathrm{z}$ found, 246.0883; calcd for $\mathrm{C}_{14} \mathrm{H}_{14} \mathrm{O}_{4}, 246.0888$.

Dimethyl 2-(4-Hydroxyphenyl)-3-isobutylmaleate (6). Colorless oil; UV $\lambda_{\max }^{\mathrm{MeOH}} \mathrm{nm}(\log \epsilon) 222.0$ (4.3), 277.0 (3.9); IR $v_{\max }^{\max } \mathrm{cm}^{-1} 3380$, 3298, 2950, 1710, 1606, 1585, 1511; for ${ }^{1} \mathrm{H}$ NMR ( $\left.\mathrm{CDCl}_{3}, 400 \mathrm{MHz}\right)$, see Table 1; for ${ }^{13} \mathrm{C}$ NMR $\left(\mathrm{CDCl}_{3}, 100 \mathrm{MHz}\right)$, see Table 2; EIMS 70 $\mathrm{eV}, m / z$ (rel intensity) $292[\mathrm{M}]^{+}$(11), 260 (100), 232 (36), 217 (86), 190 (30), 173 (21), 131 (19); HREIMS, m/z found, 292.1300; calcd, for $\mathrm{C}_{16} \mathrm{H}_{20} \mathrm{O}_{5}, 292.1305$.

3-Isobutyl-4-[4-(3-methyl-2-butenyloxy)phenyl]furan-2,5-dione (7). Yellow oil; UV $\lambda_{\max }^{\mathrm{MeOH}} \mathrm{nm}(\log \epsilon) 227.0$ (4.1), 258.0 (3.9), 275.0 (3.8), 355.0 (3.4); IR $v_{\max }^{\max } \mathrm{cm}^{-1} 1763$; for ${ }^{1} \mathrm{H}$ NMR $\left(\mathrm{CDCl}_{3}, 400 \mathrm{MHz}\right)$, see Table 1; for ${ }^{13} \mathrm{C}$ NMR $\left(\mathrm{CDCl}_{3}, 100 \mathrm{MHz}\right)$, see Table 2; EIMS $70 \mathrm{eV}$, $\mathrm{m} / \mathrm{z}$ (rel intensity) $314[\mathrm{M}]^{+}$(100), 246 (95), 131 (97).

Cell Culture and Cell Viability Assay. The RAW264.7 cell line was purchased from the Bioresource Collection and Research Center (Hsinchu, Taiwan) and cultured in DMEM containing 10\% fetal bovine serum (FBS), 2 mM glutamine, $1 \%$ nonessential amino acid, and 1 $\mathrm{mM}$ sodium pyruvate. Cells were maintained in a humidified incubator at $37{ }^{\circ} \mathrm{C}$ in $5 \% \mathrm{CO}_{2}$. For all experiments, the cells were subjected to no more than 20 cell passages. To examine the effect of the fractions of A. camphorata on cell viability, cells were plated in 96-well plates at 10000 cells per well with DMEM containing 10\% FBS. Cells were treated with various concentrations of extracts from A. camphorata in the presence or absence of $50 \mathrm{ng} / \mathrm{mL}$ LPS. Viable cell numbers were determined by the 3-[4,5-dimethylthiazol-2-yl]-2,5-diphenyltetrazolium bromide (MTT, Sigma, St. Louis, MO) assay as described previously (18).

Determination of Cytokine Production. The cytokine levels in culture supernatants were measured by sandwich ELISA methods as described by Chen and Lin (19). Briefly, the anticytokine antibodies (PharMingen, San Diego, CA) were coated in the 96-well plates (Nunc, Roskilde, Denmark) after overnight incubation at $4{ }^{\circ} \mathrm{C}$ and having been blocked with $1 \%$ BSA-PBS buffer for $30 \mathrm{~min}$. The samples and standards (recombinant mouse cytokines, PharMingen) were added to the 96-well plates for $2 \mathrm{~h}$ of incubation. The biotin-conjugated antibodies (biotinylated rat antimouse cytokine monoclonal antibodies, PharMingen) were added and incubated. After washing, streptavidinconjugated peroxidase was added for $1 \mathrm{~h}$. The substrate, 2,2'-azinobis(3ethylbenzthiazoline-6-sulfonic acid) (ABTS, Sigma), was added to each well for $20 \mathrm{~min}$. The plates were read in a microplate autoreader (Microplate autoreader; Bio-Tek Instruments, Winooski, VT) at 405 $\mathrm{nm}$.

Statistical Analysis. The data are expressed as the means \pm standard deviation of three independent experiments. The significance of difference between each treatment was analyzed by unpaired Student's $t$ test using Strategic Application Software (SAS Windows version 8.2; SAS Institute Inc., Cary, NC) throughout the study. Data are expressed as mean $\pm \mathrm{SD}$. Values at $p<0.05$ are considered to be significant.

\section{RESULTS AND DISCUSSION}

Extraction of the fruiting bodies of $A$. camphorata in a solid culture with $\mathrm{MeOH}$ followed by liquid-liquid partition resulted in the localization of anti-inflammatory activity in the EtOAc<smiles>[2H][C@]1(c2ccc(OC[CH-]C(F)=C(F)F)cc2)C(=O)NC(=O)C1(C)C(C)C(C)C</smiles>

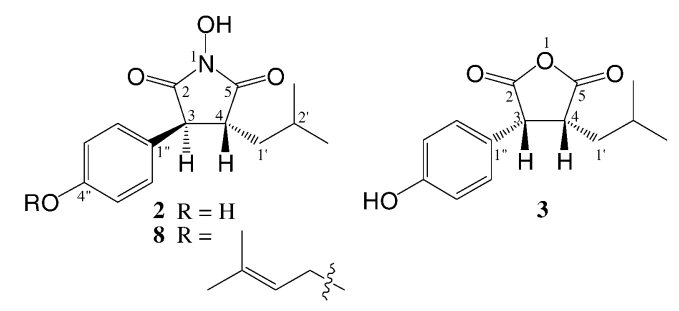<smiles>CC(C)CC1=C(c2ccc(O)cc2)C(=O)NC1=O</smiles><smiles>[Y][Y](=N)N</smiles>

Figure 1. Structures of compounds 1-9.

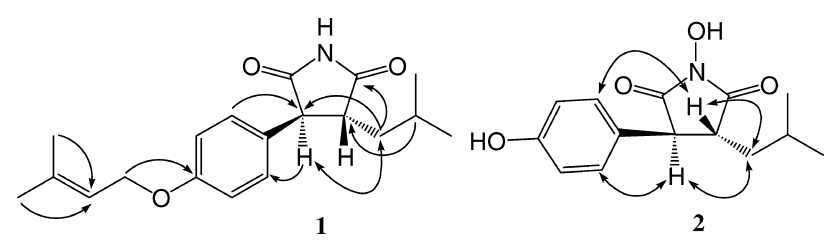

Figure 2. Key HMBC $(\rightarrow)$ and NOESY $(\leftrightarrow)$ correlations of compounds 1 and 2.

fraction. Further fractionation on a silica gel column yielded fractions rich in anti-inflammatory activity. When cells were stimulated with LPS, the concentrations for $50 \%$ inhibition of IL-6 production by crude extract and EtOAc fraction were 42 and $30 \mu \mathrm{g} / \mathrm{mL}$, respectively. The bioactive fraction was subjected to further chemical analysis to give six new compounds 1-6 and one known compound 7 (Figure 1) (8).

Compound $\mathbf{1}$ was isolated as a colorless gum. High-resolution mass spectrometry (HREIMS) revealed $\mathbf{1}$ to have the formula $\mathrm{C}_{19} \mathrm{H}_{25} \mathrm{NO}_{3}$, and the IR spectrum indicated the presence of a succinimide moiety (3256 and $1714 \mathrm{~cm}^{-1}$ ) group. The ${ }^{1} \mathrm{H}$ NMR spectrum (Table 1) showed the presence of $\mathrm{NH}$ of imide resonance at $\delta 7.94(1 \mathrm{H}$, br s), an isobutyl group at $\delta 0.71$, 0.89 ( $3 \mathrm{H}$ each, $J=6.4 \mathrm{~Hz}), 1.54(2 \mathrm{H}, \mathrm{m})$ and $1.83(1 \mathrm{H}, \mathrm{m})$, an isoprenyl group attached on $\mathrm{O}$ atom of the phenoxyl group at $\delta 1.72,1.78(3 \mathrm{H}$ each, s), $4.47(2 \mathrm{H}, \mathrm{d}, J=6.8 \mathrm{~Hz})$, and 5.46 $\left(1 \mathrm{H}\right.$, br t, $\left.J=6.8 \mathrm{~Hz}, \mathrm{H}-2^{\prime \prime \prime}\right)$, and a $p$-alkylphenoxy moiety at $\delta 6.88$ and 7.10 (each $2 \mathrm{H}, J=8.8 \mathrm{~Hz}$ ), which was further confirmed by a COSY experiment. The HMBC experiment established the connection of $\mathbf{1}$ (Figure 2). The resonances at $\delta 3.60(1 \mathrm{H}, \mathrm{d}, J=5.2 \mathrm{~Hz})$ and $2.97(1 \mathrm{H}, \mathrm{td}, J=5.2,5.2 \mathrm{~Hz})$ were assigned as $\mathrm{H}-4$ and $\mathrm{H}-3$, respectively, of the succinimide functionality by the COSY spectrum. A small coupling constant $(J=5.2 \mathrm{~Hz})(8)$ together with NOESY correlations, $\mathrm{H}-4 / \mathrm{H}_{2}-1^{\prime}$ and $\mathrm{H}-2^{\prime \prime} / \mathrm{H}-3$, elucidated two substituents in trans configuration. The ${ }^{1} \mathrm{H}$ and ${ }^{13} \mathrm{C}$ NMR resonances are similar to those of $8(8)$. The only difference between the two compounds is that 


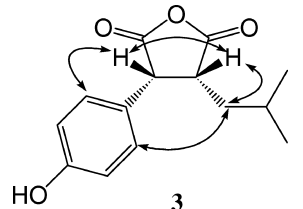

Figure 3. Key NOESY $(\leftrightarrow)$ correlations of compound $\mathbf{3}$.

compound $\mathbf{8}$ has one additional hydroxyl group on the $\mathrm{N}$ atom. Therefore, the structure of $\mathbf{1}$ can be defined as trans-3-isobutyl4-[4-(3-methyl-2-butenyloxy)phenyl]pyrrolidine-2,5-dione.

Compound 2 has the molecular formula $\mathrm{C}_{14} \mathrm{H}_{17} \mathrm{NO}_{4}$ deduced from its HREIMS and ${ }^{13} \mathrm{C}$ NMR data (Table 2). The IR spectrum showed the presence of hydroxyl $\left(3256 \mathrm{~cm}^{-1}\right)$ and maleimide carbonyl groups at $1716 \mathrm{~cm}^{-1}(8)$. The ${ }^{13} \mathrm{C}$ NMR and DEPT spectra showed signals of two methyl carbons, one methylene carbon, three methine carbons, and two carbonyl carbons, as well as one benzene ring. The ${ }^{1} \mathrm{H}$ NMR spectrum (Table 1) showed the presence of an isobutyl moiety $[\delta 0.69,0.88$ (each $3 \mathrm{H}, \mathrm{d}, J=$ $6.3 \mathrm{~Hz}), 1.60,1.75-1.85$ (each $\left.1 \mathrm{H}, \mathrm{m}, \mathrm{H}-1^{\prime}\right)$ and $1.75-1.85(1 \mathrm{H}$, $\mathrm{m}, \mathrm{H}-2)]$ and a $p$-alkylphenol moiety $[\delta 6.83,7.17$ (each $2 \mathrm{H}, \mathrm{d}, J$ $=8.5 \mathrm{~Hz}$ ) $]$. As in compound $\mathbf{1}$, two methine protons of succinimide in compound 2 appeared at $\delta 2.91(1 \mathrm{H}, \mathrm{m}, \mathrm{H}-4)$ and $3.68(1 \mathrm{H}, \mathrm{d}$, $J=5.0 \mathrm{~Hz}, \mathrm{H}-3)$. The consecutive protons were shown as follows: $\mathrm{H}-3 \rightarrow \mathrm{H}-4 \rightarrow \mathrm{H}-1^{\prime} \rightarrow \mathrm{H}-2^{\prime} \rightarrow \mathrm{H}-3^{\prime}\left(-4^{\prime}\right)$, which was revealed from the COSY spectrum. The NOESY correlations (Figure 2), $\mathrm{H}-3 / \mathrm{H}-1^{\prime}, \mathrm{H}-4 / \mathrm{H}-2^{\prime \prime}$ (-6"), and coupling constant elucidated H-3 and $\mathrm{H}-4$ are in trans configuration. A comparison of the ${ }^{1} \mathrm{H}$ and ${ }^{13} \mathrm{C}$ NMR spectra of $\mathbf{2}$ and $\mathbf{8}(8)$ showed that the only difference is that an isoprenyl group in $\mathbf{8}$ disappears in $\mathbf{2}$. On the basis of the above deduction, $\mathbf{2}$ was elucidated as a new compound named trans-1-hydroxy-3-(4-hydroxyphenyl)-4-isobutylpyrrolidine-2,5-dione. Assignment of the ${ }^{1} \mathrm{H}$ and ${ }^{13} \mathrm{C}$ NMR spectra of 2 was based on HSQC, HMBC, COSY, and NOESY.

Fourteen ${ }^{13} \mathrm{C}$ NMR resonances and exact mass spectrum data confirmed the molecular formula of 3 to be $\mathrm{C}_{14} \mathrm{H}_{16} \mathrm{O}_{4}$. The IR spectrum revealed two succinic anhydride absorptions at 1830 and $1785 \mathrm{~cm}^{-1}$. The ${ }^{1} \mathrm{H}$ NMR spectrum (Table $\mathbf{1}$ ) of $\mathbf{3}$ was similar to that of $\mathbf{2}$ and showed the presence of an isobutyl moiety at $\delta 0.91$, 0.97 (each $3 \mathrm{H}), 1.37,1.61,1.70$ (each $1 \mathrm{H}, \mathrm{m}$ ) and a para-substituted phenol $\mathrm{AA}^{\prime} \mathrm{XX}^{\prime}$ coupling system with signals at $\delta 7.20(2 \mathrm{H}, \mathrm{d}, J$ $=8.6 \mathrm{~Hz})$ and $6.75(2 \mathrm{H}, \mathrm{d}, J=8.6 \mathrm{~Hz})$. The resonance at $\delta 3.17$ $(1 \mathrm{H}, \mathrm{td}, J=11.1,3.3 \mathrm{~Hz}, \mathrm{H}-4)$ and $3.59(1 \mathrm{H}, \mathrm{d}, J=11.1 \mathrm{~Hz}$, H-3) (8) together with NOESY correlation (Figure 3) disclosed that two protons connected on succinic anhydride are in the cis form. The HMBC spectrum showed that $\mathbf{3}$ had the same partial structure as $\mathbf{2}$. Compound $\mathbf{3}$ was consequently defined as cis-3(4-hydroxyphenyl)-4-isobutyldihydrofuran-2,5-dione.

Compound 4 has the molecular formula $\mathrm{C}_{14} \mathrm{H}_{15} \mathrm{NO}_{3}$ as deduced from HREIMS and ${ }^{13} \mathrm{C}$ NMR data, which indicates eight indices of hydrogen deficiency (IHD). The IR spectrum showed an imide carbonyl absorption at $1723 \mathrm{~cm}^{-1}$. Carbon signals for two methyl carbons, one methylene carbon, one $\mathrm{sp}^{3}$ methine, one benzene ring, one olefinic group, and two carbonyl groups were shown in the ${ }^{13} \mathrm{C}$ NMR spectrum (Table 2). The ${ }^{1} \mathrm{H}$ NMR spectrum (Table 1) exhibited signals for an isobutyl moiety $[\delta 0.87(6 \mathrm{H}, \mathrm{d}, J=6.8 \mathrm{~Hz}), 1.99(1 \mathrm{H}, \mathrm{m}), 2.48(2 \mathrm{H}$, $\mathrm{m})]$ and a para-substitued phenol $[\delta 7.43$ and 6.87 (each $2 \mathrm{H}, \mathrm{d}$, $J=9.0 \mathrm{~Hz})]$. The resonance at $\delta 7.43\left(\mathrm{H}-2^{\prime \prime},-6^{\prime \prime}\right)$ correlated with $\mathrm{C}-3\left(\delta_{\mathrm{C}} 138.7\right)$ and the cross peak of $\delta 2.48\left(\mathrm{H}-1^{\prime}\right)$ coupling with $\mathrm{C}-3$ and $-4\left(\delta_{\mathrm{C}} 138.7,138.3\right)$ on HMBC spectrum and establishing the connections of $\mathrm{C}-1^{\prime \prime}-\mathrm{C}-3$ and $\mathrm{C}-1^{\prime}-\mathrm{C}-4$. In addition, the UV $\lambda_{\max }$ absorption bands of $\mathbf{4}$ are very similar to those of 9 (8). We concluded that $\mathbf{4}$ has a similar base skeleton to 9. The only difference is an additional isoprenyl group at the phenolic $\mathrm{O}$ atom in 9 . On the basis of the above deduction, 4 was elucidated as the new compound named 3-(4-hydroxyphenyl)-4-isobutyl-1H-pyrrole-2,5-dione. Assignment of the ${ }^{1} \mathrm{H}$ and ${ }^{13} \mathrm{C}$ NMR spectra of $\mathbf{4}$ was based on HSQC, HMBC, COSY, and NOESY.

Compound $\mathbf{5}$ was isolated as a yellow oil and has the molecular formula $\mathrm{C}_{14} \mathrm{H}_{14} \mathrm{O}_{4}$ based on its exact mass and ${ }^{13} \mathrm{C}$ NMR spectrum. The IR spectrum revealed carbonyl absorptions of maleic anhydride at 1838 and $1759 \mathrm{~cm}^{-1}$. Comparisons of ${ }^{1} \mathrm{H}$ and ${ }^{13} \mathrm{C}$ NMR data (Tables $\mathbf{1}$ and 2) and mass spectrum between $\mathbf{5}$ and $\mathbf{4}$ showed these two components have similar spectra, the only difference being that $-\mathrm{NH}-$ in 4 replaces $-\mathrm{O}-$ in $\mathbf{5}$. By using HSQC, HMBC, COSY, and NOESY spectra, 5 was confirmed as 3-(4hydroxyphenyl)-4-isobutylfuran-2,5-dione (20), its first isolation from nature. This compound is also an intermediate for the synthesis of camphorataanhydride A (7) (8).

Sixteen ${ }^{13} \mathrm{C}$ NMR resonance and exact mass spectrum data confirmed the molecular formula of 6 to be $\mathrm{C}_{16} \mathrm{H}_{20} \mathrm{O}_{5}$. Seven IHD were provided from the formula. The IR spectrum revealed the presence of a hydroxyl group $\left(3380 \mathrm{~cm}^{-1}\right)$ and a conjugated ester group $\left(1710 \mathrm{~cm}^{-1}\right)$. The UV $\lambda_{\max }$ at 222.0 and $277.0 \mathrm{~nm}$ confirmed the conjugated skeleton. Two methyl, one methylene, one methine, one benzene, one olefinic, and two ester carbonyl groups were shown on ${ }^{13} \mathrm{C}$ NMR and DEPT spectra. The ${ }^{1} \mathrm{H}$ NMR data showed an $\mathrm{AA}^{\prime} \mathrm{XX}^{\prime}$ coupling system resonance at $\delta$ $7.09(2 \mathrm{H}, \mathrm{d}, J=8.2 \mathrm{~Hz})$ and $6.81(2 \mathrm{H}, \mathrm{d}, J=8.2 \mathrm{~Hz})$, indicating the existence of a para-substituted phenol moiety. Two methoxy groups at $\delta 3.70$ and 3.80 correlating with $\delta_{\mathrm{C}} 168.3(\mathrm{C}-1)$ and 169.4 (C-4), respectively, on the HMBC spectrum established the connection of two carbonyl methoxy groups. The resonance at $\delta 7.09\left(\mathrm{H}-2^{\prime \prime},-6^{\prime \prime}\right)$ with the correlation with $\mathrm{C}-2\left(\delta_{\mathrm{C}} 137.5\right)$ and the cross peak between $\delta 2.14\left(\mathrm{H}-1^{\prime}\right)$ and $\mathrm{C}-2$ and $-3\left(\delta_{\mathrm{C}}\right.$ $137.5,140.1)$ on the HMBC spectrum established the connections of $\mathrm{C}-2-\mathrm{C}-1^{\prime \prime}$ and $\mathrm{C}-1^{\prime}-\mathrm{C}-3$, respectively. On the basis of the above deduction, $\mathbf{6}$ was elucidated as a new compound and named dimethyl 2-(4-hydroxyphenyl)-3-isobutylmaleate. Assignment of the ${ }^{1} \mathrm{H}$ and ${ }^{13} \mathrm{C}$ NMR spectra of 6 was based on HSQC, HMBC, COSY, and NOESY.

Macrophages are the first line of host defense against bacterial infection and cancer growth $(21,22)$. The induction of cytokine synthesis, such as tumor necrosis factor- $\alpha$ (TNF- $\alpha$ ) from macrophages is one of the methods used to evaluate the activation of innate immunity (23). We evaluated the immunomodulatory effects of these new compounds by testing the in vitro production of cytokines in RAW264.7 cells treated with the compounds. As shown in Table 3, compound $\mathbf{1}$ significantly increased spontaneous TNF- $\alpha$ secretion by RAW264.7 cells without affecting cell viability, suggesting that compound $\mathbf{1}$ may have the potential to activate macrophages. TNF- $\alpha$ levels secreted by RAW264.7 cells stimulated by $0.5-5 \mu \mathrm{g} / \mathrm{mL}$ of compound 1 increased in a dosedependent manner. Compounds 2-5 decreased the viability of RAW264.7 cells at doses over $5 \mu \mathrm{g} / \mathrm{mL}$ and had no significant effect on TNF- $\alpha$ production. Compound 6 had no effect on viability or spontaneous TNF- $\alpha$ production. These data suggest that compound $\mathbf{1}$ might be the active compound that stimulates macrophages to secret TNF- $\alpha$ without cell toxicity.

In addition, immunomodulatory effects of the new compound were evaluated by mitogen-activated macrophages. Activated macrophages secrete pro-inflammatory mediators such as TNF- $\alpha$, IL-6, IL-1 $\beta$, and nitric oxide (NO). The proper production of macrophage-derived mediators enhances the innate immune response (24), but an overproduction can result in acute phase endotoxemia and cause tissue injury, organ failure, shock, and even death (23). Macrophage cell lines, such as murine RAW264.7 and 
Table 3. Effects of Isolates from A. camphorata on Viability and Spontaneous TNF- $\alpha$ Secretion in RAW264.7 Macrophage Cells ${ }^{a}$

\begin{tabular}{|c|c|c|c|c|c|c|c|c|}
\hline $\begin{array}{l}0 \\
0.5 \\
1 \\
2 \\
5 \\
10\end{array}$ & $\begin{array}{r}100 \pm 0 \\
100 \pm 9 \\
101 \pm 8 \\
105 \pm 5 \\
99 \pm 8 \\
99 \pm 9\end{array}$ & $\begin{array}{c}100 \pm 0 \\
106 \pm 8 \\
108 \pm 9 \\
106 \pm 7 \\
95 \pm 9 \\
93 \pm 11\end{array}$ & $\begin{array}{c}100 \pm 0 \\
103 \pm 2 \\
101 \pm 3 \\
108 \pm 6 \\
100 \pm 10 \\
99 \pm 7\end{array}$ & $\begin{array}{c}\text { ability (\%) } \\
100 \pm 0 \\
106 \pm 7 \\
100 \pm 5 \\
100 \pm 5 \\
94 \pm 6 \\
90 \pm 4^{*}\end{array}$ & $\begin{array}{c}100 \pm 0 \\
91 \pm 9 \\
87 \pm 8 \\
80 \pm 9^{\star} \\
72 \pm 11^{*} \\
67 \pm 15^{\star}\end{array}$ & $\begin{aligned} 100 & \pm 0 \\
97 & \pm 13 \\
99 & \pm 4 \\
97 & \pm 5 \\
94 & \pm 7 \\
81 & \pm 8^{*}\end{aligned}$ & $\begin{array}{c}100 \pm 0 \\
101 \pm 7 \\
102 \pm 5 \\
99 \pm 6 \\
95 \pm 9 \\
86 \pm 8^{*}\end{array}$ & $\begin{aligned} 100 & \pm 0 \\
100 & \pm 6 \\
99 & \pm 7 \\
102 & \pm 6 \\
95 & \pm 8 \\
96 & \pm 11\end{aligned}$ \\
\hline
\end{tabular}

${ }^{a}$ Cells were treated with or without isolates of $A$. camphorata for $48 \mathrm{~h}$. Supernatants were collected for TNF- $\alpha$ assay, and cells were collected for viability analysis by MTT method. Data are means $\pm \mathrm{SD}$ of three independent experiments with triplicates of each. ${ }^{*}, p<0.05 ;{ }^{* *}, 0.05<p>0.1$; significantly different from the control (no extract treatment) group.

Table 4. Effects of Isolates from A. camphorata on Cell Viability and TNF- $\alpha$ and IL-6 Secretion in LPS-Stimulated RAW264.7 Macrophage Cells ${ }^{a}$

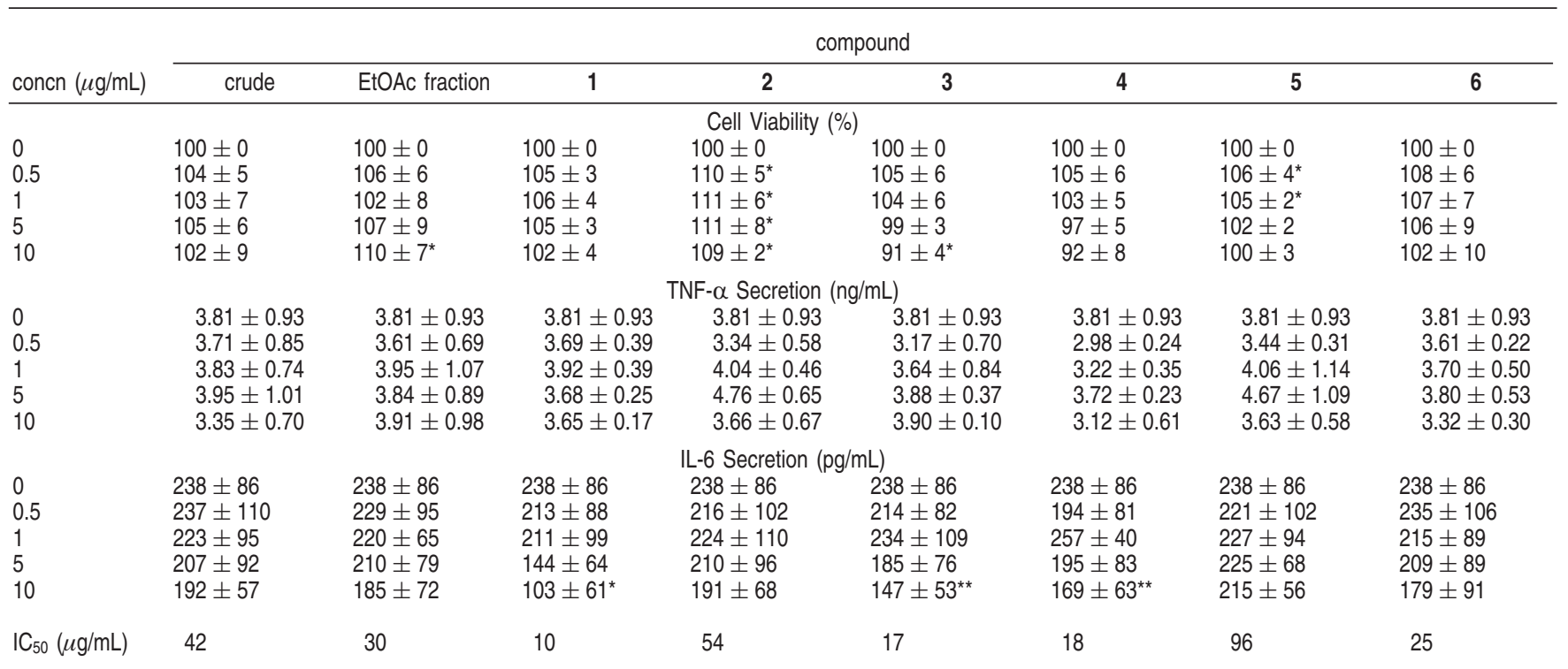

\footnotetext{
${ }^{a}$ Cells were pretreated with isolates of $A$. camphorata for $30 \mathrm{~min}$ and then stimulated with $50 \mathrm{ng} / \mathrm{mL}$ LPS for $48 \mathrm{~h}$. Supernatants were collected for TNF- $\alpha$ and IL- 6 assays, and cells were collected for viability analysis by MTT method. Data are means $\pm \mathrm{SD}$ as described under Materials ant Methods. ${ }^{*}, p<0.05 ;{ }^{* *}, 0.05<p<0.1$; significantly different from the control (no extract treatment) group.

human THP-1, have been proposed as rapid in vitro screening methods to test the anti-inflammatory agents (25). In this study, LPS stimulation significantly increased TNF- $\alpha$ (3.81 \pm 0.93 vs $0.05 \pm 0.02 \mathrm{ng} / \mathrm{mL})$ and IL-6 (238 $\pm 86 \mathrm{vs} 48.5 \pm 3.8 \mathrm{pg} / \mathrm{mL})$ secretions (data not shown). The effect of pretreatment of new compounds from A. camphorata on TNF and IL-6 secretions by LPS-stimulated RAW264.7 cells is shown in Table 4. In general, these compounds did not affect the viability of RAW264.7 macrophages. However, at $10 \mu \mathrm{g} / \mathrm{mL}$, compounds $\mathbf{2}$ and $\mathbf{5}$ increased cell viability, whereas compound $\mathbf{3}$ decreased cell viability. When cells were stimulated with LPS, TNF- $\alpha$ secretions were not significantly affected; however, IL-6 production was significantly decreased by compound $\mathbf{1}$ in a dose-dependent manner. The concentration required for $50 \%$ inhibition $\left(\mathrm{IC}_{50}\right)$ of $\mathrm{IL}-6$ production by compound $\mathbf{1}$ was $10 \mu \mathrm{g} / \mathrm{mL}$. Compounds $\mathbf{3}, \mathbf{4}$, and $\mathbf{6}$ also suppressed IL- 6 production. They had $\mathrm{IC}_{50}$ values 17,18 , and 25 $\mu \mathrm{g} / \mathrm{mL}$, respectively. Compounds $\mathbf{2}$ and $\mathbf{5}$ had the least effect on IL-6 production. They had $\mathrm{IC}_{50}$ values of 54 and $96 \mu \mathrm{g} / \mathrm{mL}$, respectively.

The wild-type fruiting body of $A$. camphorata is well-known as an effective and expensive folk remedy for many diseases. Anti-

inflammatory activity of $A$. camphorata has been suggested to contribute to the prevention of neurodegenerative diseases through suppression of both the inducible nitric oxide synthetase and cyclooxygenase-2 expression in mouse microglia cell line (15). Furthermore, Rao et al. showed that methanol extracts from $A$. camphorata inhibited macrophage-mediated inflammatory mediators such as NO and TNF- $\alpha$ in LPS/IFN $\gamma$-activated mouse peritoneal macrophages (26). IL-6, a pro-inflammatory cytokine that is a useful marker of infection, is secreted by monocytes and macrophages in many infectious and inflammatory states, including cardiac surgery, cardiogenic shock, coronary bypass, and bacteria sepsis (27-29). The serum concentration of IL-6 has been reported to correlate with disease severity (30). IL-6 production from LPSstimulated macrophages, from cell lines, and from primary cells was also significantly decreased by anti-inflammatory drugs, such as pyrrolidine dithiocarbamate (24). In the present study, compound 1 from the methanol extract of A. camphorata enhanced spontaneous TNF secretion, but decreased IL-6 production from LPSactivated macrophage without affecting cell viability, suggesting that compound $\mathbf{1}$ is the most effective compound of methanol
} 
extracts from A. camphorata, exerting both immunostimulatory and anti-inflammatory effects.

In summary, we identified six new compounds, three succinic derivatives (compounds $\mathbf{1 - 3}$ ) and three maleic derivatives (compound 4-6), together with one known compound from the fruiting bodies of A. camphorata. Compound $\mathbf{1}$ significantly activated macrophages to secret TNF- $\alpha$, indicating that it is a potential immunostimulator. Compounds 1, 3, 4, and $\mathbf{6}$ significantly suppressed LPS-stimulated IL-6 from RAW264.7 macrophages. These data suggest that these four compounds may have an antiinflammatory effect in macrophage-mediated responses. Among these compounds isolated from A. camphorata, compound $\mathbf{1}$ was the most effective, exerting both immunostimulatory and antiinflammatory effects.

\section{LITERATURE CITED}

(1) Shen, C. C.; Kuo, Y. C.; Huang, R. L.; Lin, L. C.; Don, M. J.; Chang, T. T.; Chou, C. J. New ergostane and lanostane from Antrodia camphorata. J. Chin. Med. 2003, 14, 247-258.

(2) Chang, T. T.; Chou, W. N. Antrodia cinnamomea sp. nov. on Cinnamomea kanehirai in Taiwan. Mycol. Res. 1995, 99, 756-758.

(3) Cherng, I. H.; Chiang, H. C. Three new triterpenoids from Antrodia cinnamomea. J. Nat. Prod. 1995, 58, 365-371.

(4) Shen, Y. C.; Wang, Y. H.; Chou, Y. C.; Chen, C. F.; Lin, L. C.; Chang, T. T.; Tien, J. H.; Chou, C. J. Evaluation of the antiinflammatory activity of zhankuic acid isolated from the fruiting bodies of Antrodia cinnamomea. Planta Med. 2004, 70, 310-314.

(5) Hsiao, G.; Shen, M. Y.; Lin, K. H.; Lan, M. H.; Wu, L. Y.; Chou, D. S.; Lin, C. H.; Su, C. H.; Sheu, J. R. Antioxidative and hepatoprotective effects of Antrodia camphorata extract. J. Agric. Food Chem. 2003, 51, 3302-3308.

(6) Shen, Y. C.; Chou, C. J.; Wang, Y. H.; Chen, C. F.; Chou, Y. C.; $\mathrm{Lu}, \mathrm{M}$. K. Anti-inflammatory activity of the extracts from mycelia of Antrodia camphorata cultured with water-soluble fractions from five different Cinnamomum species. FEMS Microbiol. Lett. 2004, 231, 137-143.

(7) Wang, G. J.; Tseng, H. W.; Chou, C. J.; Tsai, T. H.; Chen, C. T.; Lu, M. K. The vasorelaxation of Antrodia camphorata mycelia: involvement of endothelial $\mathrm{Ca}^{2+}-\mathrm{NO}-\mathrm{cGMP}$ pathway. Life Sci. 2003, 73, 2769-2783.

(8) Nakamura, N.; Hirakawa, A.; Gao, J. J.; Kakuda, H.; Shiro, M.; Komatsu, Y.; Sheu, C. C.; Hattori, M. Five new maleic and succinic acid derivatives from the mycelium of Antrodia camphorata and their cytotoxic effects on LLC tumor cell line. $J$. Nat. Prod. 2004, 67, 46-48.

(9) Chen, C. H.; Yang, S. W.; Shen, Y. C. New steroid acids from Antrodia cinnamomea, a fungal parasite of Cinnamomum micranthum. J. Nat. Prod. 1995, 58, 1655-1661.

(10) Yang, S. W.; Shen, Y. C.; Chen, C. H. Steroids and triterpenoids of Antrodia cinnamomea-a fungus parasitic on Cinnamomum micranthum. Phytochemistry 1996, 41, 1389-1392.

(11) Cherng, I. H.; Chiang, H. C.; Cheng, M. C.; Eang, Y. Three new triterpenoids from Antrodia cinnamomea. J. Nat. Prod. 1995, 58, 365-371.

(12) Chiang, H. C.; Wu, D. P.; Cherng, I. W.; Ueng, C. H. A sesquiterpene lactone, phenyl and biphenyl compounds from Antrodia cinnamomea. Phytochemistry 1995, 39, 613-616.

(13) Wu, D. P.; Chiang, H. C. Constituents of Antrodia cinnamomea. J. Chin. Chem. Soc. 1995, 42, 797-800.

(14) Cherng, I. H.; Wu, D. P.; Chiang, H. C. Triterpenoids from Antrodia cinnamomea. Phytochemistry 1996, 41, 263-267.

(15) Liu, D. Z.; Liang, H. J.; Chen, C. H.; Su, C. H.; Lee, T. H.; Huang, C. T.; Hou, W. C.; Lin, S. Y.; Zhong, W. B.; Lin, P. J.; Hung, L. F.; Liang, Y. C. Comparative anti-inflammatory characterization of wild fruiting body, liquid-state fermentation, and solid-state culture of Taiwanofungus camphoratus in microglia and the mechanism of itsaction. J. Ethnopharmacol. 2007, 113, 45-53.
(16) Chen, C. C.; Shiao, Y. J.; Lin, R. D.; Shao, Y. Y.; Lai, M. N.; Lin, C. C.; Ng, L. T.; Kuo, Y. H. Neuroprotective diterpenes from the fruiting body of Antrodia camphorata. J. Nat. Prod. 2006, 69, 689-691.

(17) Chen, J. J.; Lin, W. J.; Liao, C. H.; Shieh, P. C. Anti-inflammatory benzenoids from Antrodia camphorata. J. Nat. Prod. 2007, 70, 989-992.

(18) Cho, H. J.; Kim, W. K.; Kim, E. J.; Jung, K. C.; Park, S.; Lee, H. S.; Tyner, A. L.; Park, J. H. Conjugated linoleic acid inhibits cell proliferation and ErbB3 signaling in HT-29 human colon cell line. Am. J. Physiol. Gastrointest. Liver Physiol. 2003, 284, 996-1005.

(19) Chen, M. L.; Lin, B. F. Effects of triterpenoid-rich extracts of Ganoderma tsugae on airway hyperreactivity and Th2 responses in vivo. Int. Arch. Allergy Immunol. 2007, 143, 21-30.

(20) Baag, M. M.; Argade, N. P. Synthesis of natural cytotoxic camphorataimides B and C. Synthesis 2006, 100, 5-1008.

(21) Higgins, S. E.; Erf, G. F.; Higgins, J. P.; Henderson, S. N.; Wolfenden, A. D.; Gaona-Ramirez, G.; Hargis, B. M. Effect of probiotic treatment in broiler chicks on intestinal macrophage numbers and phagocytosis of Salmonella enteritidis by abdominal exudate cells. Poult. Sci. 2007, 86, 2315-2321.

(22) Verstovsek, S.; Maccubbin, D.; Ehrke, M. J.; Mihich, E. Tumoricidal activation of murine resident peritoneal macrophages by interleukin 2 and tumor necrosis factor alpha. Cancer Res. 1992, 52, 3880-3885.

(23) Meisner, M.; Schmidt, J.; Schywalsky, M.; Tschaikowsky, K. Influence of pyrrolidine dithiocarbamate on the inflammatory response in macrophages and mouse endotoxin shock. Int. J. Immunopharmacol. 2000, 22, 83-90.

(24) Kuo, M. C.; Weng, C. Y.; Ha, C. L.; Wu, M. J. Ganoderma lucidum mycelia enhance innate immunity by activating NF- $\kappa \mathrm{B}$. J. Ethnopharmacol. 2003, 103, 217-222.

(25) Singh, U.; Tabibian, J.; Venugopal, S. K.; Devaraj, S.; Jialal, I. Development of an in vitro screening assay to test the antiinflammatory properties of dietary supplements and pharmacological agents. Clin. Chem. 2005, 51, 2252-2256.

(26) Rao, Y. K.; Fang, S. H.; Tzeng, Y. M. Evaluation of the antiinflammatory and anti-proliferation tumoral cells activities of Antrodia camphorate, Cordyceps sinensis, and Cinnamomum osmophloeum bark extracts. J. Ethnopharmacol. 2007, 114, 78-85.

(27) Hövels-Gürich, H. H.; Vazquez-Jimenez, J. F.; Silvestri, A.; Schumacher, K.; Minkenberg, R.; Duchateau, J.; Messmer, B. J.; von Bernuth, G.; Seghaye, M. C. Production of proinflammatory cytokines and myocardial dysfunction after arterial switch operation in neonates with transposition of the great arteries. J. Thorac. Cardiovasc. Surg. 2002, 124, 811-820.

(28) Geppert, A.; Steiner, A.; Zorn, G.; Delle-Karth, G.; Koreny, M.; Haumer, M.; Siostrzonek, P.; Huber, K.; Heinz, G. Multiple organ failure in patients with cardiogenic shock is associated with high plasma levels of interleukin-6. Crit. Care Med. 2002, 30, 19871994.

(29) Kantar, M.; Kültürsay, N.; Kütükcüler, N.; Akisü, M.; Cetingül, N.; Caglayan, S. Plasma concentrations of granulocyte-macrophage colony-stimulating factor and interleukin-6 in septic and healthy preterms. Eur. J. Pediatr. 2000, 159, 156-157.

(30) Pathan, N.; Hemingway, C. A.; Alizadeh, A. A.; Stephens, A. C.; Boldrick, J. C.; Oragui, E. E.; McCabe, C.; Welch, S. B.; Whitney, A.; O'Gara, P.; Nadel, S.; Relman, D. A.; Harding, S. E.; Levin, M. Role of interleukin 6 in myocardial dysfunction of meningococcal septic shock. Lancet 2004, 363, 203-209.

Received for review April 14, 2008. Revised manuscript received June 11, 2008. Accepted June 11, 2008. This research was supported by the National Science Council of the Republic of China.

JF801171X 